\title{
Lifelong good soldiers of higher education institutions: driving factors and obstructions of alumni loyalty
}

\author{
Shih-Hao Wu ${ }^{1}$. Stephen Chi-Tsun Huang ${ }^{1} \cdot$ Ching-Yi Daphne Tsai ${ }^{2}$
}

Received: 22 April 2021 / Accepted: 13 December 2021 / Published online: 21 January 2022

(C) The Author(s), under exclusive licence to Springer-Verlag GmbH Germany, part of Springer Nature 2021

\begin{abstract}
Loyal customers are good soldiers who behave favorably toward service firms. As increasing number of universities are facing "a candle burning at both ends" due to low birth rate and high global competition, this study integrates alumni participation, alternative attractiveness, school prestige, and the relationship quality-based student loyalty model to verify leading variables that enhance alumni loyalty. A total of 412 questionnaires were collected from universities in Taiwan. Other than service quality and relationship quality, this study confirms the critical influence of alumni participation and school prestige on loyalty intention. The key mediation role of alumni participation is also revealed.
\end{abstract}

Keywords Alumni loyalty $\cdot$ Participation $\cdot$ School prestige $\cdot$ Higher education service $\cdot$ Relationship marketing

"I think a relationship is like a shark. It has to constantly move forward or it dies."-Woody Allen

Ching-Yi Daphne Tsai

cydtsai@nutc.edu.tw

Shih-Hao Wu

paul@nkust.edu.tw

Stephen Chi-Tsun Huang

clivehuang.tw@gmail.com

1 Department of Marketing and Distribution Management, National Kaohsiung University of Science and Technology, No. 2, Jhuoyue Rd., Nanzih District, Kaohsiung 811, Taiwan

2 Department of Business Management, National Taichung University of Science and Technology, No. 129, Sec. 3, Sanmin Rd, North District, Taichung 404, Taiwan 


\section{Introduction}

Loyal customers are willing to devote their physical, mental, and emotional efforts to cooperating with firms (e.g., Bendapudi and Leone 2003; Koc et al. 2017) and are viewed as good soldiers (Yi and Gong 2008). As higher education institutions (HEIs) worldwide are experiencing "a candle burning at both ends" due to low birth rate and high global competition, stakeholder loyalty is viewed as a key factor for universities' survival and success (Chang et al. 2013; Hsueh 2019; Marioulas 2019; Snijders et al. 2019). Yet, formal research on the driving factors of loyalty in HEIs is scant (Brown and Mazzarol 2009; Schlesnger et al. 2017). Much of the research on HEI relationship marketing (RM) focuses on the importance of relationship quality (e.g., Helgesen and Nesset 2007; Wong and Wong 2011; Olavarría-Jaraba et al. 2018), service quality (Fares et al. 2013), school reputation (Alves and Raposo 2010; Thomas 2011), perceived value (Brown and Mazzarol 2009), and relationship evolution (Gallo 2013). Among all, the study of Hennig-Thurau and colleagues (2001) has made a great contribution on the research of RM in HEI by proposing the relationship quality-based student loyalty (RQSL) model to reveal how relationship quality (RQ, e.g., trust and commitment) built at school influences alumni loyalty. However, in the RQSL model, the key constructs (e.g., student loyalty and trust) are examined as complex constructs containing several critical elements. As such, the influence made by these critical elements individually may be overlooked.

Later, researchers suggest that the impact of stimulus on customer loyalty may decline as the relationship extends, which echoes the statement of that a relationship needs to constantly move forward, otherwise, it dies. Thus, to profitably manage stakeholders, firms must facilitate the relationship from the loyalty stage to the "engagement" stage (Pansari and Kumar 2017). Engaging customer is a way to upgrade relationship to a higher level of sustainable competitive advantage and desired differentiation. It also improves firm performance and is an important indicator for valuing customers (Pansari and Kumar 2017). Customer engagement refers to interactions and connections, both individual and organization initiated, which an individual participates in or possesses with an organization's offerings or organizational activities (Vivek et al. 2012). It is commonly found in the HEI context as the practice of students and alumni participating in school activities. Such participation practice has been identified as a key factor driving favorable behaviors (e.g., alumni giving) for the school (Holmes 2009). Accordingly, this study builds upon the RQSL model and takes one step further to examine how HEIs can better trigger loyalty behaviors through managing alumni participation.

To strengthen the completeness of the RQSL model, this study also incorporates two key constructs which people frequently encounter when engaging with HEIs. The first one is school prestige, a key construct drawing people close to the school. Research in sport reveals that fans tend to bask in reflected glory (BIRG) by revealing their associations with the winning team when the team they support experiences a successful season (Cialdini et al. 1976; Tajfel 1981). Contrarily, when the team fails, fans cut off reflected failure (CORF) by avoiding actions demonstrating associations with the losing team (Funk et al. 2000). 
School prestige is the outcome of a school's performance which may further trigger stakeholder's BIRGing or CORFing reaction. Yet, relevant discussions are scarce in HEI which may neglect some important insights.

The other construct adopted is alternative attractiveness (AA), as a construct turning people's interest from the school to other schools. Alternative attractiveness is widely used in retailing to assess consumer's switching tendency (e.g., Singh and Rosengren 2020). It refers to "customers' perceptions of the extent to which viable competing alternatives are available in the marketplace" (Ghazali et al. 2016, p. 159). People are motivated to switch to other firms that provide offerings with better performance than that of provided by the current ones (Dick and Basu 1994). Moreover, the highly competitive condition of the HEI market enlarges the influence of competitors, or AAs, on stakeholders' behavior decisions. Attracting students from other schools has become a key strategy for HEIs to raise their enrollment rates. Thus, AA is incorporated into the proposed model as a control variable.

Based on the above rationale, the research question guiding this study is, "how the perceived experiences gained at school trigger HEI stakeholders' loyalty intentions with impacts from participation, other attractions, and obstructions?" Alumni, the only lifelong HEI stakeholders and constantly growing in numbers (Gallo 2013), are selected as the research objects in this study. Each year, thousands of college students graduate and transform into alumni. Many of them are active participants who may interact with their alma mater as donors, field lecturers, employers or parents of students, or even students once again (Gallo 2013). As such, HEIs benefit from the engagement behaviors of these good soldiers financially (e.g., donation, service patronage), promotionally (e.g., word-of-mouth, school reputation), and value-collaboratively (e.g., experience sharing in class).

This article makes several contributions to academia and practices. First, we incorporate the complex construct of student loyalty from the RQSL model and breakdown into three individual constructs to clarify the impacts made by each of the loyalty elements. Second, we single out the effect of participation in alumni associations (as participation construct in the proposed model) since such effect is a key mediator in the relationship between alumni and their alma maters. Third, we incorporate school prestige to highlight the importance of HEI's reputation and brand image. Fourth, we also consider the impacts of AA as the control variable to make the model more comprehensive.

In the subsequent parts of this article, we offer a literature review and state the research hypotheses, followed by our explanations of the research method. We, then, present the results of the hypothesis testing, examined by partial least squares (PLS) with data from graduates of a Taiwanese public institution. Lastly, we set forth conclusions, implications, and suggestions for further research. 


\section{Literature review}

\subsection{The relationship quality-based student loyalty (RQSL) model}

Relationship quality is a higher-order construct containing several distinct but related dimensions (Hennig-Thurau et al. 2001; Roberts et al. 2003), and it varies according to the research context (Osobajo and Moore 2017). Researchers incorporate RQ to describe how strong or healthy a relationship is and refer it as individuals' overall perception of the quality of the relationship they are in (Snijders et al. 2020). Hennig-Thurau et al. (2001) propose their RQSL model depicting that former students' loyalty toward the institution is developed while studying in this particular school. The service quality (SQ) students perceive at school, the trust they have toward the HEI's personnel, and the commitment they feel toward the HEI are the key constructs affecting their loyalty toward the alma mater after they graduate.

\subsubsection{Service quality}

In an educational context, SQ is a long-run overall assessment of a student toward the institution they attend and is an important driver for both student and alumni loyalty (Hennig-Thurau et al. 2001). It is a form of attitude resulting in an evaluative perception of the service consumption experience from the buyers' perspective and best assessed by performance-based measurements (Cronin and Taylor 1992; Fornell et al 1996).

\subsubsection{Relationship quality: trust and commitment}

As a multi-dimensional construct, RQ often composites trust and commitment (Hennig-Thurau et al. 2001). Trust is the key factor for a successful relationship (Morgan and Hunt 1994) and the most powerful RM tool for a service firm (Berry 1995). It is 'the willingness to rely on an exchange partner in whom one has confidence' (Moorman et al. 1993, p. 82). In the RQSL model, trust refers to students' confidence in the integrity and reliability of an HEI's personnel which is generated through students' personal experiences with faculty members (Hennig-Thurau et al. 2001). However, researchers have observed that the objects of one's trust could be different, for example, trust toward sales people and toward service firms, toward physicians and toward hospitals, as well as fans' trust toward sports players and toward the team (Wu et al. 2012; Huang et al. 2014).

Trust toward different objects generates diverse impacts on loyalty and should be treated separately (e.g., Sirdeshmukh et al. 2002; Palmatier et al. 2007; Wu et al. 2012). In the education context, several types of trust have been identified including student trust in faculty, student trust in principal, faculty trust in principal, faculty trust in colleagues, faculty trust in clients (parents and students), parent trust in school, parent trust in principal, etc. (Forsyth et al. 2011). To meet with the research question and to better analyze trust in this study, other than trust in faculty, we also incorporate trust in institution into our model. 
Commitment is a core construct in service and organization literature, as well as in education marketing studies like Hennig-Thurau et al. (2001). Commitment refers to the intention of an individual to continue the relationship with a firm (Dwyer et al. 1987; Morgan and Hunt 1994). Such intention may be driven by different motivations and can be categorized into various types of commitment (Geyskens et al. 1996). In the RQSL model, Hennig-Thurau et al. (2001) examine the effects of different types of commitment on student loyalty. To better meet with the aim of this study, we incorporate cognitive commitment and emotional commitment into our model and examine the impacts they generate on alumni's loyalty intention.

Both cognitive and emotional commitments are psychological states of alumni regarding their attitudes and beliefs about the relationship with the institution and are formed with different motivations (Geyskens et al. 1996). The perception of the need to maintain a relationship with the institution based on the calculation of costs and benefits of staying or leaving the relationship is the center of cognitive commitment (Geyskens et al. 1996; Hennig-Thurau et al. 2001). For emotional commitment, the underlying motive for alumni to continue the relationship with their alma mater is because they like the institution and enjoy the partnership (Hennig-Thurau et al. 2001). To avoid the repetition of emotional commitment and trust in institution, we combine these two constructs into a higher-order construct, institution RQ.

In addition, goal commitment, referring to individuals' determination to try for a goal (Hollenbeck \& Klein 1987), is also incorporated in our model. According to the social-cognitive theory, an individual's goal is an aspect of his/her motivation, selfregulation, and achievement (Bandura 1991; Zimmerman et al. 1992). Students of HEIs have the commitment to the achievement of their goals which not only direct their engagement in academic tasks or activities, but also energize their behaviors (Locke and Latham 2002; Baker 2019).

\subsection{Loyalty intention}

Loyalty is a commitment to a firm to respond in a way that benefits the firm directly or indirectly by, for example, re-patronizing firm's product/service or spreading good words about the firm. Such commitment is persistent and resistant to change and influences people's cognitive thoughts and behaviors (Schlesinger et al. 2017). Loyalty contains both attitudinal and behavioral components (Hennig-Thurau et al. 2001). No consensus has been reached on what is preferred between the two perspectives since each explains loyalty in different research contexts. Attitudinal loyalty refers to people's emotions, and intentions to re-patronage or recommend (Park and Kim 2000), and has been identified as the key predictor of actual behavior (Ajzen and Driver 1992). Alumni loyalty is highly important for their alma mater (Helgesen and Nesset 2007), especially when the market size is shrinking and becoming more competitive.

Similarly, former students' intentions to do good word-of-mouth (WOM) about their alma mater, to re-patronage the same service, or to attend cross-disciplinary and advanced education programs offered by the school are critical for HEIs' performance and are examined in this study as alumni loyalty intention. WOM is one 
of the most discussed and relevant dimensions of loyalty (Moliner-Velázquez et al. 2021). The digitalized social networking environment has increased the importance of WOM. People recommending their alma mater on social networking sites helps attract prospective students for the school. In addition, the re-patronage intention of service usage represents direct value contribution tendency of alumni. Different from the intention of purchasing the same service, alumni's patronage intention of joining the recurrent courses for other academic skills and graduate employability (Schuetze and Slowey 2002), or obtaining upper degrees is an up-scale cross-buying intention.

In order to eliminate the confusion caused by incorporating business terminologies to the educational context, we made necessary modifications on the commonly used business terms of re-patronage intention and cross-buying intention. For the former construct, we termed it as the re-patronage intention of service usage for examining alumni's willingness to purchase the same services from the school. The latter construct of capability/degree upgrading intention was re-named as "capability/degree upgrading intention" to describe the intention of attending cross-disciplinary or advanced education programs. The comparison of these two terminologies and their operational definitions is shown in Table 1.

\subsection{Participation}

Engaging customers is an important strategy for firms because it enhances brand and firm performance (Verhoef et al. 2010; Kumar and Pansari 2016). Evidence shows that the amount spent by engaged customers with a service firm is higher than that of by disengaged customers (Sorenson and Adkins 2014). Service firms tend to increase customer participation to assure their own financial performance (Kumar et al. 2019). In service literature, participation is the extent to which a customer is involved in the production and delivery of a service by contributing physical, mental, and emotional inputs (Bendapudi and Leone 2003; Koc et al. 2017). Thus, in this study, participation refers to alumni's voluntary behavior to interact with alumni associations by, for example, joining alumni programs or attending activities. Such voluntary behavior shows the willingness of alumni to maintain the relationship with their alma mater.

Table 1 Comparison of terminologies

\begin{tabular}{lll}
\hline Terminology in business & Terminology in education & Operational definition \\
\hline Re-purchase intention & Re-patronage intention of service usage & $\begin{array}{c}\text { Alumni's willingness to purchase } \\
\text { the same services from the } \\
\text { school if they faced the same } \\
\text { choice again }\end{array}$ \\
Cross-buying intention & Capability/degree upgrading intention & $\begin{array}{c}\text { The intention of alumni to accept } \\
\text { additional programs or classes } \\
\text { offered by their alma mater }\end{array}$ \\
\hline
\end{tabular}




\subsection{School prestige}

School prestige, or reputation, is a multi-facet subjective construct referring to the actual perception of a school held by its stakeholders (Brown et al. 2006; O'Loughlin et al. 2015; Wilkins and Huisman 2015). The prestige of a university is a key influencer on attracting prospective students, faculty, and funding (O'Loughlin et al. 2015). Moreover, individuals graduating from prestigious HEIs are given greater socioeconomic opportunities because employers hold higher expectations about these employees' ability (Trusheim and Crouse 1981).

\subsection{Control variable}

Alternative attractiveness (AA) refers to customers' overall assessment of the competing service organization which draws their attention and interest in the available market (Jones et al. 2000). The higher the perceived attraction of the competing service organization as an alternative, the higher the likelihood that consumers will leave from the existing relationship to its competitor. Extant research has evidenced the links between AA and consumers' attitude, commitment, and behaviors (Wu 2011; Ghazali et al. 2016; Kim et al. 2018a, b). In our research setting, AA would negatively influence alumni's RQ and loyalty intentions, especially re-patronage intention of service usage and capability/degree upgrading intentions. Alumni would choose other HEIs with stronger attractions as recurrent education outlets instead of their alma mater. Therefore, we control for AA in our model.

\subsection{Hypotheses development}

The relationship among SQ, RQ, and loyalty is well documented. SQ is one of the most critical antecedents of RQ (Crosby et al. 1990; Roberts et al. 2003; Hsieh and Hiang 2004). How well a company's performance is perceived highly influences its customers' RQ levels. Moreover, buyers' RQ (trust and commitment) toward a firm influences their behaviors (Morgan and Hunt 1994). For example, a more committed customer is inclined to give positive WOM or perform voluntary behaviors than a less committed customer. Schlesnger et al. (2017) also argue that RQ is critical on alumni-engaging behaviors. Accordingly, we postulate the relationships among SQ, trust in faculty, institution RQ, and the three loyalty constructs that:

H1 Service quality has a positive impact on trust in faculty.

H2a Trust in faculty has a positive impact on institution RQ.

H2b Service quality has a positive impact on institution RQ.

H3a-c Institution RQ has a positive impact on (a) WOM, (b) capability/degree upgrading intention and (c) re-patronage intention of service usage. 
Literature shows that the RQ level between a service provider and its customer is positively related to the possibility of the customer continuously interacting with the service firm (Liang et al. 2011). As such, when the RQ between alumni and their alma mater is high, alumni are more trusting and committed with the services provided by the school and will be willing to stay in the relationship with the school by, in this case, participating in school associations or activities (Gustafsson et al. 2005; Shabbir et al. 2007). Alumni participation has been identified as a key factor driving favorable behaviors (for example, alumni giving) for the school (Holmes 2009). Thus, we hypothesize that:

H3d Institution RQ has a positive impact on participation.

H4 Participation has a positive impact on (a) WOM, (b) capability/degree upgrading intention, and (c) re-patronage intention of service usage.

Consisting with $\mathrm{H} 3$, the impact of commitment (e.g., cognitive commitment) on loyalty intentions is well documented (e.g., Hennig-Thurau et al. 2001; Schlesnger et al. 2017). Extant studies also provide evidence on the relationship between the level of students' goal commitment and their loyalty behavior (Tinto 1993; Baker 2019). The consumption of education service is much longer in length than other services. The longer the consumption period is, the more external challenges students may face which forces students to reformulate their goals and reevaluate their relationship with the school (Hennig-Thurau et al. 2001). How much students commit to their own goal will influence how much they are willing to coproduce with the school and faculty members in class and outside of class. Thus, we postulate that:

H5 Cognitive commitment has a positive impact on (a) WOM, (b) capability/degree upgrading intention, and (c) re-patronage intention of service usage.

H6 Goal commitment has a positive impact on (a) WOM, (b) capability/degree upgrading intention, and (c) re-patronage intention of service usage.

The positive impact of school prestige on HEI stakeholders' behavior intention is evident. Extending from the BIRGing and CORFing effect, school prestige influences the behavior tendency of alumni on whether or not to show the associations with the school by, for example, participating in activities for alumni. Other than that, relationship connections, business opportunities, or even job opportunities are additional attractions that trigger alumni's willingness to participate in relevant associations. Moreover, the more alumni participate in relevant associations, the more they are inclined to engage in positive responses to the school (Holmes 2009). As such, we hypothesize that:

H7 School prestige has a positive impact on (a) WOM, (b) capability/degree upgrading intention, and (c) re-patronage intention of service usage. 


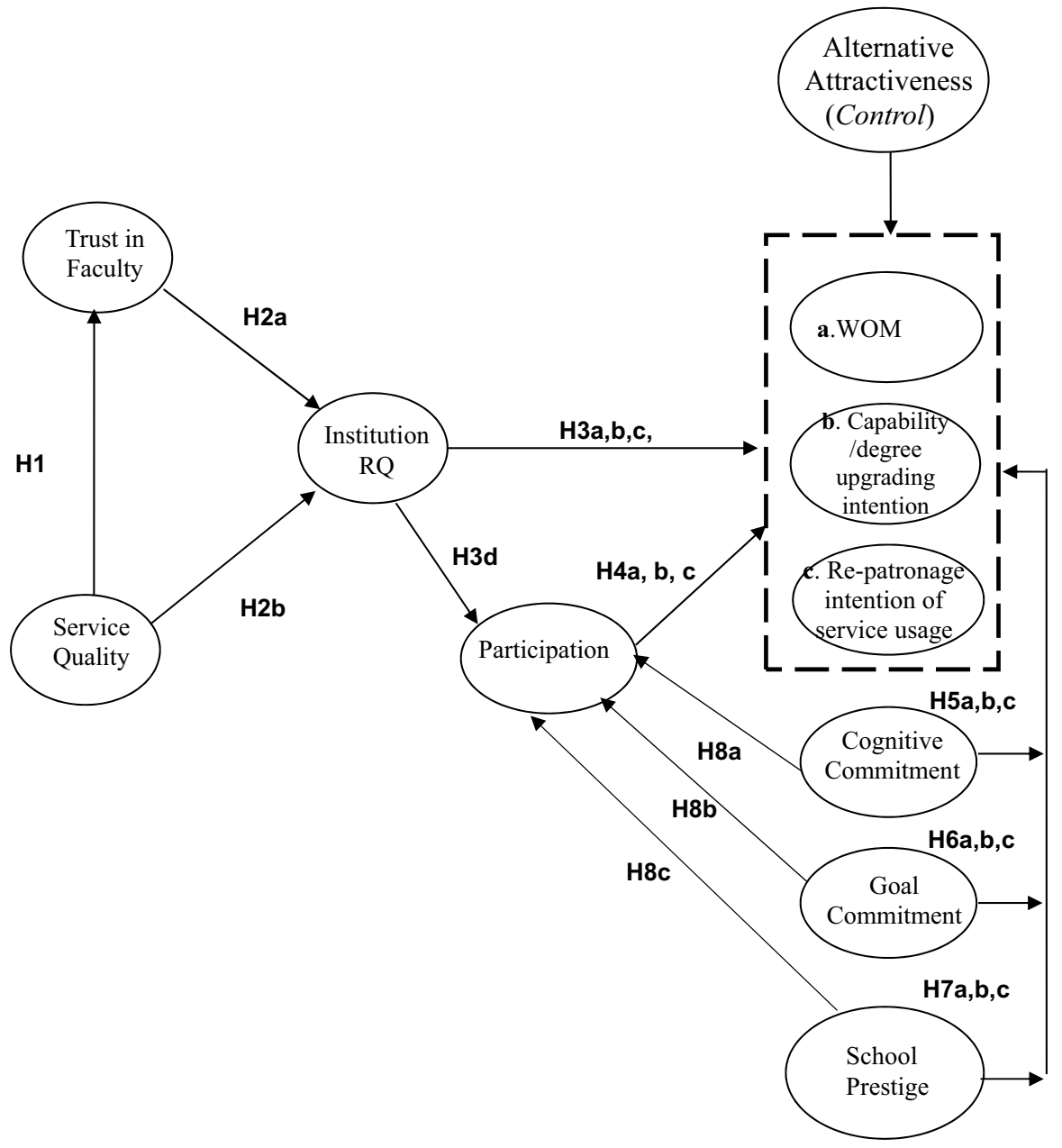

Fig. 1 Research model framework

H8 (a) Cognitive commitment, (b) goal commitment, (c) school prestige have a positive impact on participation.

Figure 1 depicts the framework of this study.

\section{Research method}

\subsection{Research setting}

The HEI system in Taiwan has experienced a series of quick expansion and reform in the past 30 years and has obtained its high reputation on education quality. 
However, having one of the lowest birth rates in the world and facing the attractions coming from other famous HEIs around the world, HEIs in Taiwan are just like "a candle burning at both ends" (Hsueh 2019; Marioulas 2019). The enrollment is expected to drop from 219,000 in 2020 to 162,000 by 2028 (Ministry of Education 2018). Such trend will affect the HEI system and will force approximately 20 to 40 universities (out of 165) to close down within the next few years. Under such highly competitive environment, HEIs are in urgent need of effective strategies to manage student/alumni loyalty. Thus, the Taiwanese HEI is a suitable research context to clarify how universities' efforts influence alumni's consequent behavioral intentions (Manzoor et al. 2020).

\subsection{Measures and sample}

Measures in this research either came from or were modified from previous studies (See Appendix Table 5). Extending from Hennig-Thurau et al. (2001), SQ was operationalized as the evaluation of three core dimensions including teaching-related structures (e.g., school infrastructure and the condition of the academic staff), teaching-related processes (e.g., courses, exams, and the concern of faculty members toward students), and actual outcomes or usefulness perceived by students or alumni of their studies for meeting challenges (Hennig-Thurau et al. 2001). Moreover, researchers suggested that SQ is a formed attribute because it is "the sum total of a number of specific activities that make up the overall performance of a particular industry's service" (Rossiter 2002, p. 314). The dimensions that construct a formed attribute are causes of the attribute rather than its effects (Diamantopoulos et al. 2008). Thus, aligning with prior studies (e.g., Collier and Bienstock 2006; Ulaga and Eggert 2006), SQ was treated as a formative variable in this study.

Trust in faculty was defined as students' confidence in the institution's faculty members' integrity and reliability and measured by two items from Hennig-Thurau et al. (2001). Institution RQ was composed of trust in institution and emotional commitment. The former was operationalized as an alumnus' willingness to rely on his/ her alma mater in which he/she has confidence, and the latter was defined as an alumnus' emotional attachment and sense of belongingness toward HEI-related objects (e.g., faculty members and the school). Two items each were adapted from Moorman et al. (1993) and Hennig-Thurau et al. (2001), respectively. This study defined WOM as the willingness of individuals to make recommendation or say good words about their alma mater to others. Items were modified from HennigThurau et al. (2001). Following Ngobo (2004), capability/degree upgrading intention was operationalized in this study as the intention of alumni to accept additional programs or classes offered by their alma mater. Extending from Hennig-Thurau et al. (2001), this study defined re-patronage intention of service usage as alumni's willingness to purchase the same services from the school if they faced the same choice again. Similarly, based on the concept of Hennig-Thurau et al. (2001), participation was measured as alumni's willingness to participate in activities arranged by their old school or department. 
This study referred to Verhoef et al. (2002) and defined cognitive commitment as the extent to which alumni perceived the need to stay in the relationship with the school due to the anticipated termination or switching costs of leaving. Following Hennig-Thurau et al. (2001), the single item was adopted to measure goal commitment as the extent to which alumni's commitment to the achievement of their own goals. This study modified items from Mael and Ashforth (1996) and measured school prestige as the degree to which the school is well regarded. Lastly, alternative attractiveness was operationalized as alumni's perception of a full range of services and overall service satisfaction provided by another school (Sharma and Patterson, 2000). The variables were anchored using a 5-point Likert scale ranging from (5) "strongly agree" to (1) "strongly disagree."

To ensure language equivalency, this study undertook the translation and backtranslation procedure (Hambleton 1993) to develop the Chinese version questionnaire. Two researchers who were fluent in both languages participated in the translation process independently. One researcher translated the study instrument from its original English version (A) into Chinese (B), and then the other researcher translated the Chinese version (B) back to English (C). Two bilingual marketing professors who were specialized in RM examined questionnaires $\mathrm{A}, \mathrm{B}$, and $\mathrm{C}$ to avoid misinterpretation. The results indicated that the major items in the Chinese version (B) were the same as those in the original English version (A). Only a few minor revisions were undertaken by the two professors for the Chinese version (B) to accommodate to the cultural differences. In-depth interviews and a pre-test of 34 alumni from a private university were also conducted to help improve the wording of the measures.

Then, a list of alumni with contact information was obtained from the student affair office of a national university in Taiwan. Initially, an e-mail from the head of the student affair office was sent to these alumni and invited them to respond to the questionnaire online. Four hundred and ninety questionnaires were returned to the research team. However, 78 of them were incomplete, resulting in 412 usable questionnaires.

\subsection{Model testing and methods}

The hypotheses were tested with the partial least squares (PLS), a widely used modeling technique of causality (Bhattacherjee et al. 2012), for several reasons. First, the strength of PLS is its function of handling various variables and clarifying relationships among them. Such function makes PLS the right analytical tool for complex models like the one presented in this study (Fornell and Larcker 1981; Hair et al. 2017). Second, PLS can be used to relax errors with its distribution-free assumptions which is especially helpful because data collected from surveys are usually neither normally distributed, nor error-free in most social science disciplines. Further, because of its merit of distribution-free, PLS is more powerful for predictive models. PLS is not only capable in handling a complex model with many variables and relationships (Hair et al. 2017), but also capable in dealing with reflective and 
formative measurement models simultaneously (Fornell and Larcker 1981; Hair et al. 2017), like the framework in this study.

This study employed a two-step PLS analysis (Hult et al. 2019). The measurement validity was examined to ensure that the measures of underlying constructs were both reliable and valid, then, followed by the structural validity to interpret the resulting model coefficients. To test the significance of the measures and structural coefficients, we further used a bootstrapping method to derive average coefficients, standard errors, and t-values (Hair et al. 2017). We then employed tests using bootstrapping methods with PLS analysis to test the mediation effects (Sarstedt et al. 2020).

\section{Results}

\subsection{Reliability and validity of the measurement model}

The analysis results of the measurement model, showing high loadings of the items on their corresponding factors (see Appendix Table 5), provided support for reliability (Anderson and Gerbing 1988). Furthermore, adequate convergent validities of reflective constructs were revealed not only in both the acceptable average variance extracted (AVEs $>0.50$ ) and high composite reliability (CRs $>0.70$ ), but also in their reliability of high internal consistency (Cronbach's alpha) (Hair et al. 2017). Due to the self-reported nature of the data, the Harman one-factor test was thus conducted to test common method bias. The unrotated factor analysis showed that the first factor accounted for only 26.9 percent of the variance, lower than 50 percent. Thus, the common method variance was not considered significant.

We employed both the Fornell-Larcker criterion and the heterotrait-monotrait (HTMT) inference ratio method to examine the discriminant validity of the constructs. The correlations of the constructs are shown in panel (A) of Table 2. After comparing the square root of AVE of each construct and the correlation of this construct with the other ones, we found that the former is larger than the latter indicating strong discriminant validity of the questionnaire (Fornell-Larcker criterion 1981). Further, the HTMT matrix also revealed that the criteria of discriminant validity were met for this study, as shown in panel (B) of Table 2. The HTMT ratio of each pair of constructs is lower than the thresholds of 0.85 and 0.90 (Hair et al. 2017).

\subsection{Model fit and prediction power}

Since PLS does not provide statistics to measure overall model fit, $R^{2}$ and $Q^{2}$ are used to indicate the model fit and predictive relevance (Hair et al. 2017). The coefficients of the determination $R^{2}$ values in this model show some effects, because all the variances of endogenous latent constructs are explained for over $25 \%$, as revealed in Table 3. For instance, SQ explains 57\% of the variance of trust in faculty, while the former two constructs together explained $65 \%$ variance of institution RQ. Besides, our proposed model explains 60, 39, and 53\% of the variances of WOM, 


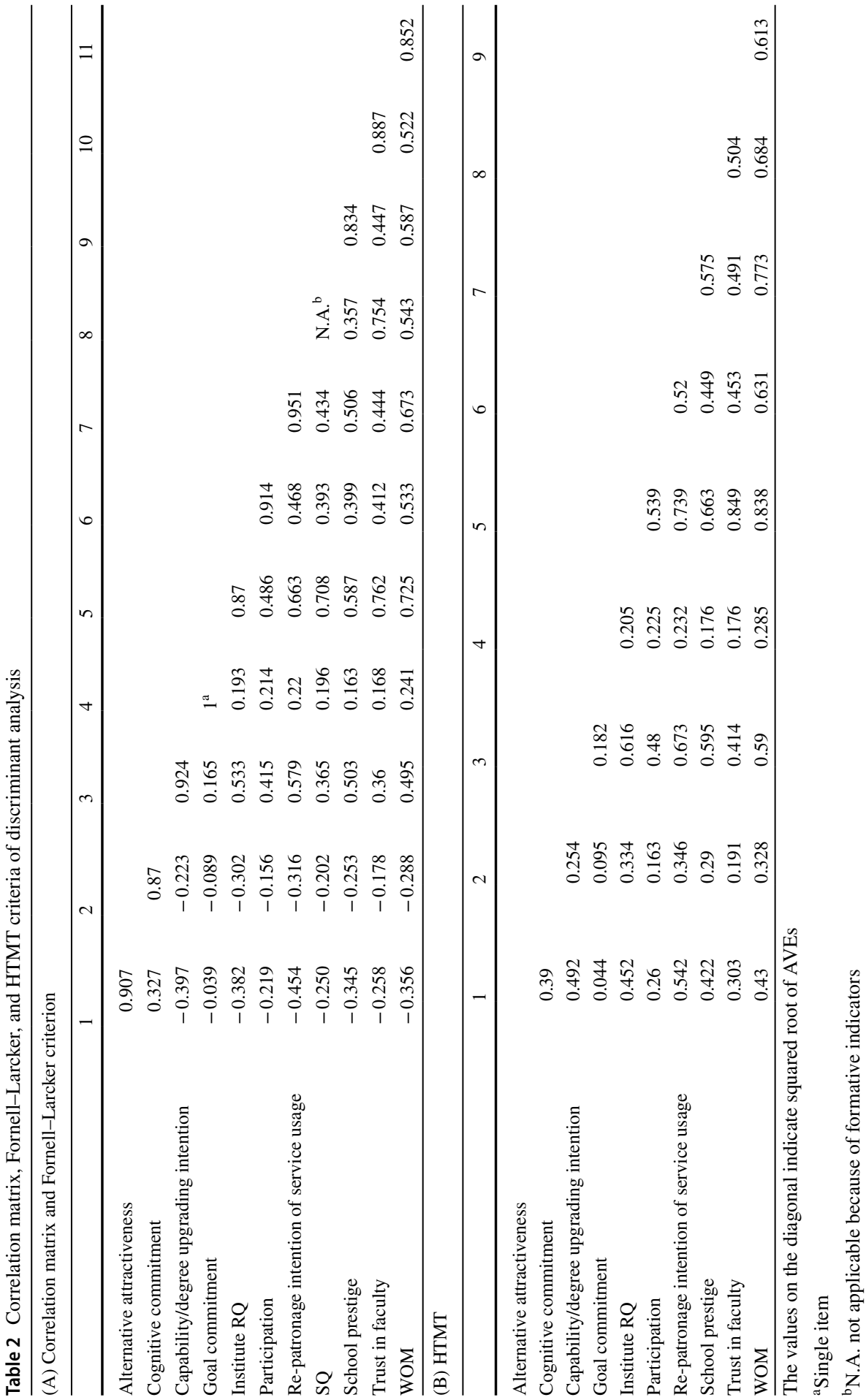




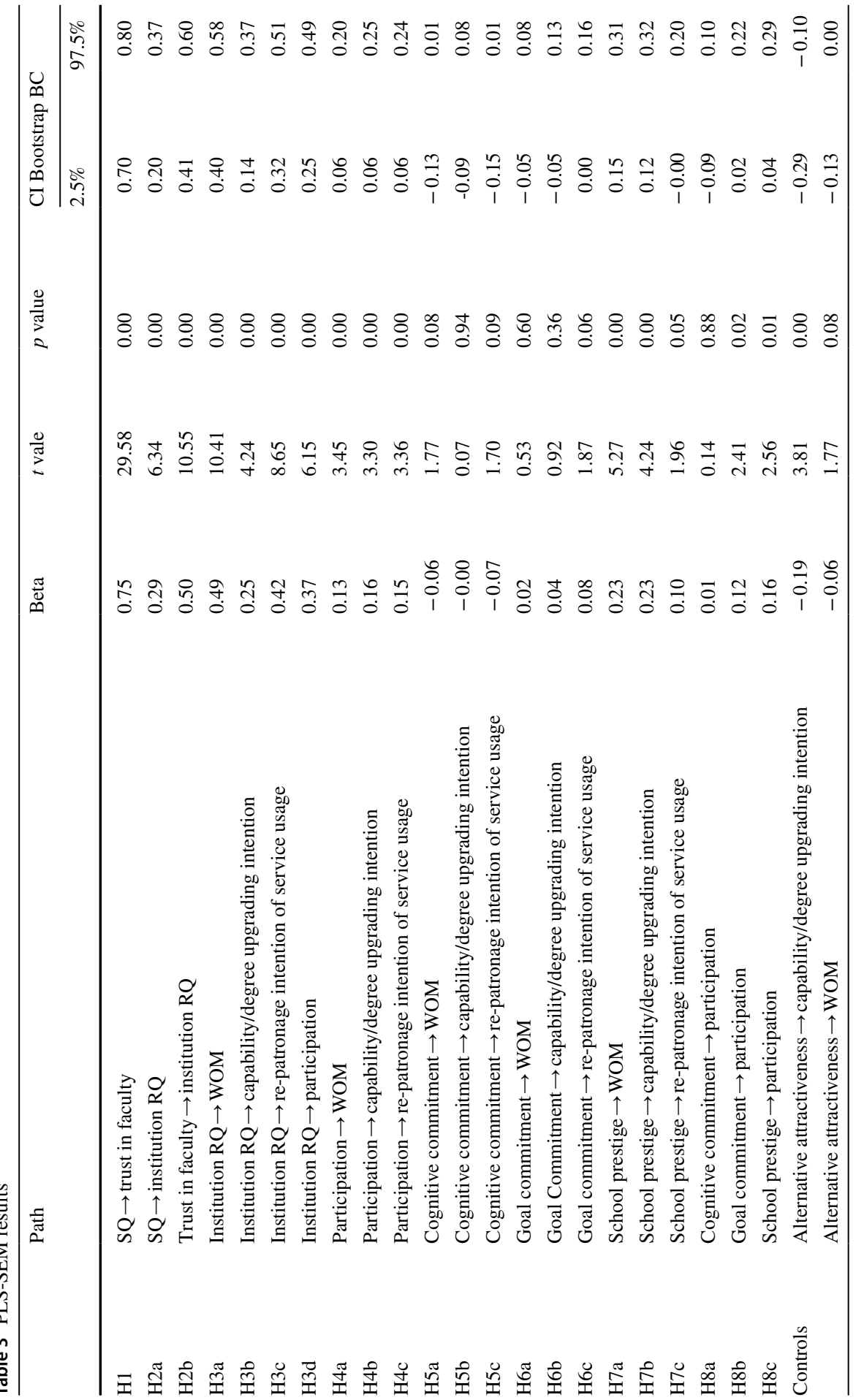




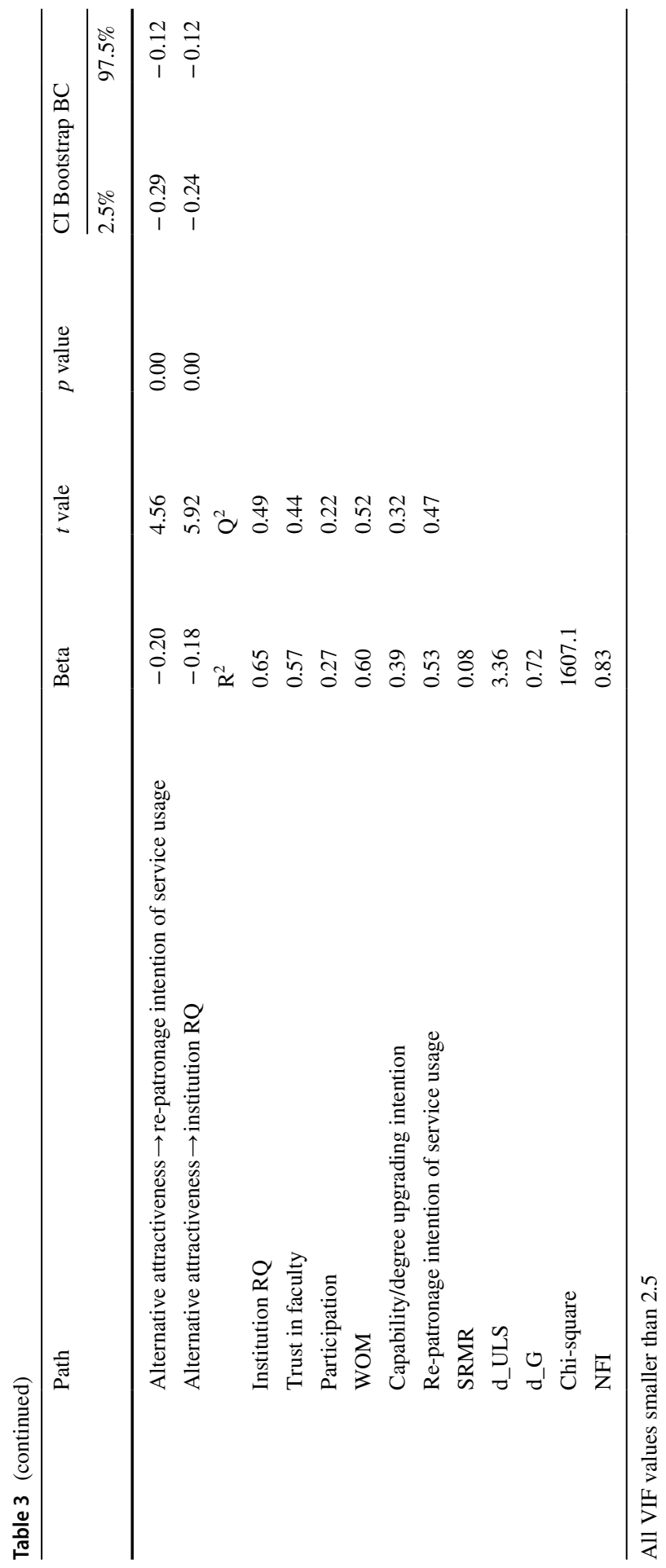


capability/degree upgrading intention, and re-patronage intention of service usage, respectively.

In addition, the blindfolding procedure returned a positive $Q^{2}$ confirming the predictive relevance of the model. The $Q^{2}$ figures for the three consequent behavioral intentions, WOM (0.52), capability/degree upgrading intention (0.32), and repatronage intention of service usage (0.47), indicated clear support for the model's predictive relevance. The SRMR value (0.08) met the threshold of good model fit of covariance-based SEM. Such threshold is considered as a more rigorous requirement for PLS-SEM cases, like our study (Hair et al. 2017, p. 193), meaning that the SRMR of this model is more acceptable. These outcomes indicated the satisfactory confirmation of the model fit. Table 3 presents the results of our PLS analysis.

\subsection{SEM results}

We examined the SEM results (structural model validity) and the specific paths of interest. Following previous research, we controlled the effects of AA on the consequence constructs, including institution RQ, re-patronage intention of service usage, capability/degree upgrading intention, and WOM, to better measure the real effects of the proposed constructs. These links were significant as expected (see Table 3). As for the results of interest, first, the effect of SQ on trust in faculty was significantly positive $(\beta=0.75, p<0.01)$, indicating that $\mathrm{H} 1$ was supported. Second, both SQ $(\beta=0.29, p<0.01)$ and trust in faculty $(\beta=0.50, p<0.01)$ significantly impacted institution RQ, meaning that both $\mathrm{H} 2 \mathrm{a}$ and $\mathrm{H} 2 \mathrm{~b}$ were supported. Third, institution RQ further positively influenced the three consequent behavioral intentions: WOM $(\beta=0.49, p<0.01)$, capability/degree upgrading intention $(\beta=0.25, p<0.01)$, and re-patronage intention of service usage $(\beta=0.42, p<0.01)$, as well as participation $(\beta=0.37, p<0.01)$. Thus, all Hypotheses $3 \mathrm{a}, 3 \mathrm{~b}, 3 \mathrm{c}$, and $3 \mathrm{~d}$ were supported.

As expected, participation had positive impacts on WOM $(\beta=0.13, p<0.01)$, capability/degree upgrading intention $(\beta=0.16, p<0.01)$, and re-patronage intention of service usage $(\beta=0.15, p<0.01)$ indicating a significant support for $\mathrm{H} 4 \mathrm{a}$, $4 \mathrm{~b}$, and $4 \mathrm{c}$. In contrast, Hypotheses $5 \mathrm{a}, 5 \mathrm{~b}$, and $5 \mathrm{c}$ were not supported because the impacts of cognitive commitment on WOM $(\beta=-0.06, p>0.05)$, capability/degree upgrading intention $(\beta=0.00, p>0.05)$, and re-patronage intention of service usage $(\beta=-0.07, p>0.05)$ did not reach the significant threshold. The results for H6a-c were not supported either. The effects of goal commitment on the three behavioral intentions, WOM $(\beta=0.02, p>0.05)$, capability/degree upgrading intention $(\beta=0.04, p>0.05)$, and re-patronage intention of service usage $(\beta=0.08, p>0.05)$, did not reach the significant threshold for H6a-c. Furthermore, H7a-c were supported because the impacts of school prestige on WOM $(\beta=0.23, p<0.01)$, capability/degree upgrading intention $(\beta=0.23, p<0.01)$, and re-patronage intention of service usage $(\beta=0.10, p<0.05)$ were all significant. Finally, participation was significantly influenced by goal commitment $(\beta=0.12, p<0.05)$ and school prestige $(\beta=0.16, p<0.05)$, but not by cognitive commitment $(\beta=0.01, p>0.05)$, and therefore, H8a-c were partially supported. 
Table 4 Indirect effects via participation (mediation tests)

\begin{tabular}{|c|c|c|c|c|c|}
\hline \multirow[t]{2}{*}{ Participation as a mediator } & \multirow[t]{2}{*}{ I.E. } & \multirow[t]{2}{*}{$\mathrm{t}$} & \multirow[t]{2}{*}{$\mathrm{p}$} & \multicolumn{2}{|c|}{$\begin{array}{l}\text { CI } 95 \% \text { Bias } \\
\text { Corrected } \\
(\%)\end{array}$} \\
\hline & & & & 2.50 & 97.5 \\
\hline Institute $\mathrm{RQ} \rightarrow$ participation $\rightarrow$ WOM & 0.071 & 3.497 & 0.000 & 0.04 & 0.12 \\
\hline $\begin{array}{l}\text { Institute } R Q \rightarrow \text { participation } \rightarrow \text { capability/degree upgrading inten- } \\
\text { tion }\end{array}$ & 0.057 & 2.816 & 0.005 & 0.02 & 0.10 \\
\hline $\begin{array}{l}\text { Institute } R Q \rightarrow \text { participation } \rightarrow \text { re-patronage intention of service } \\
\text { usage }\end{array}$ & 0.057 & 2.808 & 0.005 & 0.02 & 0.10 \\
\hline Cognitive commitment $\rightarrow$ participation $\rightarrow$ WOM & 0.001 & 0.146 & 0.884 & -0.02 & 0.02 \\
\hline $\begin{array}{l}\text { Cognitive commitment } \rightarrow \text { participation } \rightarrow \text { capability/degree } \\
\text { upgrading intention }\end{array}$ & 0.001 & 0.145 & 0.885 & -0.01 & 0.02 \\
\hline $\begin{array}{l}\text { Cognitive commitment } \rightarrow \text { participation } \rightarrow \text { re-patronage intention } \\
\text { of service usage }\end{array}$ & 0.001 & 0.146 & 0.884 & -0.01 & 0.02 \\
\hline Goal commitment $\rightarrow$ participation $\rightarrow$ WOM & 0.023 & 2.139 & 0.032 & 0.01 & 0.05 \\
\hline $\begin{array}{l}\text { Goal commitment } \rightarrow \text { participation } \rightarrow \text { capability/degree upgrading } \\
\text { intention }\end{array}$ & 0.018 & 1.821 & 0.069 & 0.00 & 0.04 \\
\hline $\begin{array}{l}\text { Goal commitment } \rightarrow \text { participation } \rightarrow \text { re-patronage intention of } \\
\text { service usage }\end{array}$ & 0.018 & 1.850 & 0.064 & 0.00 & 0.04 \\
\hline School prestige $\rightarrow$ participation $\rightarrow$ WOM & 0.032 & 2.372 & 0.018 & 0.01 & 0.06 \\
\hline $\begin{array}{l}\text { School prestige } \rightarrow \text { participation } \rightarrow \text { capability/degree upgrading } \\
\text { intention }\end{array}$ & 0.026 & 2.023 & 0.043 & 0.01 & 0.06 \\
\hline $\begin{array}{l}\text { School prestige } \rightarrow \text { participation } \rightarrow \text { re-patronage intention of } \\
\text { service usage }\end{array}$ & 0.025 & 2.334 & 0.020 & 0.01 & 0.05 \\
\hline
\end{tabular}

\subsection{Mediation tests}

To further examine the mediating effects of participation on the links between three antecedents (institution RQ, cognitive and goal commitments, school prestige) and three consequents (WOM, capability/degree upgrading intention, re-patronage intention of service usage), we employed tests using bootstrapping methods (Hair et al. 2017) with PLS analysis under a simultaneously overall testing setting (Sarstedt et al. 2020). The results are shown in Table 4. All the mediating effects were significant with 5000 subsample bootstrapping method, except for the path from cognitive commitment, indicating a partial mediation effect of participation. These mediation tests presented that participation in alumni associations mediated most of the relationships between antecedents and the three behavioral intentions, except those from cognitive commitment. For instance, participation mediated the links from school prestige to WOM (indirect effect: $\mathrm{IE}=0.032, p<0.05$ ), capability/degree upgrading intention ( $\mathrm{IE}=0.026, p<0.05$ ), and re-patronage intention of service usage ( $\mathrm{IE}=0.025, p<0.05)$. Summarily, participation in alumni association played a critical role in triggering alumni's positive behaviors, such as giving positive WOM, capability/degree upgrading intention, and purchasing more service usages from their alma mater. 


\section{Discussion and conclusion}

The aim of this study is to advance the literature for higher education marketing by clarifying how different levels of the driving factors trigger alumni loyalty. This study builds upon the RQSL model and takes one step further to examine how HEIs can better trigger loyalty behaviors through managing alumni participation. Moreover, two constructs, school prestige (drawing people close to the school) and alternative attractiveness (drawing people close to other schools), are also incorporated to strengthen the completeness of the proposed model. All the hypotheses in our model were supported, except those triggered by cognitive and goal commitments.

Evidence has demonstrated the relationship between commitment and loyalty (e.g., Morgan and Hunt 1994; Hennig-Thurau et al. 2001; Pedro et al. 2020). Both constructs are multi-dimensional. Different commitments may generate distinct impact on loyalty constructs. The results of this study show that the influence from cognitive commitment to all the loyalty constructs is insignificant which is consistent with the finding of Kumar et al. (1994). The reason might be that cognitive commitment is considered as a negative motivation to continue a relationship (Geyskens et al. 1996). People stay in a relationship may be a result of spurious loyalty which would unlikely drive people to perform voluntary behaviors (e.g., WOM, re-patronage intention of service usage, participation), especially after they are "set free" from the perceived lock-in relationship (Hennig-Thurau et al. 2001; Verhoef et al. 2002).

The links from goal commitment to WOM, capability/degree upgrading intention, and re-patronage intention of service usage are also insignificant. When individuals with high goal commitment, they strive to achieve their personal goals. As the list of alumni provided by the student affair office for this study contained mostly those who graduated in less than 3 years, these freshmen of the labor force devoted majority of their time to work-related tasks and activities. At this early career stage, they might not have a clear idea of the skills they would need later. Thus, going back to school for more training courses or diplomas might not in their to-do list. Moreover, students with high goal commitment may struggle from balancing heavy school work and personal goal achievement throughout college years. Such experience might not be something that alumni would like to go through again. That explains why goal commitment did not trigger alumni's loyalty intentions.

\subsection{Theoretical contribution}

Several findings deserved to be highlighted. First, our findings confirm the multidimensional nature of loyalty in higher education marketing. As we broke down Hennig-Thurau et al.'s (2001) single loyalty construct into participation, WOM, and re-patronage intention of service usage, we found that each of these subconstructs plays different role in the relationship between alumni and their alma mater. Second, this study reveals the initiation role of participation on the aforementioned loyalty intentions. Our findings show that participation in alumni association triggers alumni's intention to WOM, capability/degree upgrading intention, and re-patronage 
intention of service usage. Thus, participation in alumni association is not only a strong tie for alumni with their alma mater, but also triggers loyalty behaviors which further contribute to the school.

Third, based on the perspective of HEIs, this study categorizes the antecedents of alumni loyalty behaviors into the manageable and unmanageable factors. The former includes those constructs that can be managed by HEIs (e.g., SQ, trust in faculty, institution RQ, and school prestige), while the latter refers to those that cannot be managed by HEIs including alumni's personal commitment (i.e., cognitive commitment and goal commitment) and AA. The findings show that the manageable factors generate greater impact on alumni's behavioral intentions than those unmanageable factors do. Personal commitment, especially cognitive commitment, rarely impacts alumni's behavioral intentions. The goal commitment has a slightly direct influence on WOM and re-patronage intention of service usage and a marginally indirect effect on capability/degree upgrading intention via participation in alumni association. Cognitive commitment has no impact in this study. As expected, AA influences capability/degree upgrading intention and re-patronage intention of service usage, but with no effect on WOM indicating that AA is related to purchase decision rather than WOM. Our research echoes Hennig-Thurau et al. (2001) that SQ, trust in faculty, and institution RQ are critical for universities to trigger alumni's behavioral intentions. If one did not experience decent SQ, nor build trust in faculty and high institution RQ with the university they attended, the relationship between the person and his/her alma mater would be fragmented or awful (Hashim et al. 2020; Pedro et al. 2020) which would neither trigger positive WOM nor encourage usage of further education services (Snijders et al. 2020).

Fourth, other than the variables proposed by Hennig-Thurau et al. (2001), we incorporated school prestige in the model. Our results confirm the critical role of school prestige and the BIRGing or CORFing effects it may generate (Campbell et al. 2004; Yoshida et al. 2014). Alumni act like sport fans who tend to bask in reflected glory or to cut off reflected failure (Funk et al. 2000). A school with good reputation may encourage its alumni's response of revealing their association with the school. Contrarily, a school with poor reputation can be seen as a losing team in sport and may drive alumni's distancing behavior (Campbelll et al. 2004; Yoshida et al. 2014). Moreover, our findings show that school prestige significantly enhances alumni's capability/degree upgrading intention, WOM, re-patronage intention of service usage, and participation in alumni association. As such, to maintain or to improve school prestige is crucial for HEIs because it strengthens their relationship with alumni and also incurs further exchanges.

Fifth, the results of this study show that institution RQ, including trust and commitment, highly influences WOM, capability/degree upgrading intention, and repatronage intention of service usage and participation. Service quality and trust in faculty also indirectly influence these constructs. Such results are in line with the findings of previous studies (e.g., Perin et al. 2012; Snijders et al. 2019, 2020; Hashim et al. 2020). In addition, we found that the relationships between cognitive commitment and three loyalty constructs were nonsignificant. Unlike emotional commitment which was included in institution RQ, cognitive commitment is considered having calculative nature (Hennig-Thurau et al. 2001). Students may end 
their relationship with the school once they receive their diploma. As taking a closer look at the correlation matrix (see Table 2), we found that cognitive commitment, as does AA, has negative correlations with the other constructs proposed in this model. Contrarily, goal commitment has significantly positive and direct relationships with WOM and re-patronage intention of service usage and an indirect link with capability/degree upgrading intention through participation. Such result depicts that student's goal commitment is a bridge between HEIs and their alumni which further triggers positive WOM in alumni's social circles.

\subsection{Practical implications}

The findings of this study offer several managerial implications which are helpful for HEIs to allocate resources more effectively. First of all, alumni are the only lifelong stakeholders who may continuously offer support to the school. To raise alumni's engagement and loyalty intention, HEIs should enhance alumni's perception of SQ and increase their trust and commitment levels toward institution and faculties. Such enhancement should be taken place even when the alumni are still in college. In a relational exchange, individuals' positive consumption experiences influence their future behaviors (Yuan and $\mathrm{Wu}$ 2008; Chen and $\mathrm{Hu}$ 2010). This is especially salient in the service industry in which the core service is to offer intangible experience to consumers. HEIs obtain competitive advantages through maximizing students' perceived value by offering them memorable experience during their college years (Yuan and $\mathrm{Wu} 2008$ ). Universities are encouraged to strengthen the service quality of their administration staff, the functions of teaching equipment, course variety, and faculty teaching quality. Faculties are also recommended to enhance their relationship with students and to strengthen the social bond with them. In service, satisfied people feel obligated to reciprocate by doing extra work that benefits the service firm (Kim and Lee 2013). Accordingly, alumni voluntary behaviors (e.g., WOM, participation) can be expected.

Second, HEIs are recommended to segment their alumni by, for example, age, professions, locations, year of graduation, and so on, and to manage alumni participation in relevant associations differently. Our findings reveal that participation in alumni association is a critical engagement behavior and a key mediator in the relationship between institution RQ and other behavioral intentions. HEIs are encouraged to invite alumni to join school social networking sites and to design activities (e.g., connecting with people you met in college, saying hello to your teachers, providing information about job opportunities) to attract alumni's attention. Customization should also be incorporated into alumni activities. For example, alumni associations may plan a homecoming event with customized topics for different generations to recall their memory of the good old days in college and may also involve alumni to design the newsletters for their own segment. Moreover, customized incentives or promotion strategy can be used to attract different alumni generations to recommend their family members, relatives, or friends to their alma mater.

Third, our results confirm that alumni are like sports fans to BIRG when their alma mater owns a good reputation and to CORF when the school fails (Campbell 
et al. 2004; Yoshida et al. 2014). Our study reveals the importance of school prestige in triggering alumni's capability/degree upgrading intention, WOM, re-patronage intention of service usage, and participation in alumni association behaviors. School prestige is also a key indicator for universities to attract potential students. Thus, HEIs are recommended to increase their reputation by recruiting teachers with well-known research performance, providing better school facilities/equipment, and offering attractive incentives to encourage academic performances. HEIs are also suggested to improve their global ranking by constantly providing and updating the related ranking associations with necessary information (O'Loughlin et al. 2015). Moreover, building up students' entrepreneurship and enhancing their abilities by providing related courses, incorporating incubation hubs or angel funds to offer hands-on experiences is an effective way for HEIs to gain a better reputation. Conducting university social responsibility (USR) programs to interact with local communities and to help resolve social issues is also a way to obtain respects and positive publicities for HEIs.

Fourth, in addition to maintaining alumni loyalty, HEIs are recommended to incorporate the "untact" strategy extensively. Contrary to contact, "untact" means "no contact" which was created to depict service provided without face-to-face encounters between service providers and consumers (Kim et al. 2018a, b; Lee and Lee 2020). The Covid-19 pandemic has changed universities to "never be the same" (Witze, 2020). Students remain home and turn to online courses to continue their studying. Such virtual teaching, or untact service, allows universities to not only give online course, but also hold special forums or activities for their alumni without being constrained by distance. For example, Philip Kolter, a well-known marketing guru, gave an online talk to alumni of University of Northwest regarding the pandemic and future global development in marketing (see https://www.youtube.com/ watch? $\mathrm{v}=1$ OPLZGLOfY8). Untact interactions like this strengthen the perceived SQ of students and alumni, enhance their RQ toward the school, and further trigger their loyalty behaviors. Virtual teaching makes possible of holding lectures given by well-known foreign or out-of-state adjunct teachers because it eliminates the obstacles caused by high travel expenses and time-consuming processes. Moreover, virtual teaching can also become a highlight of the university by offering a study abroad program (SAP) of combining online courses with tourism (Shin et al. 2018) to attract international students. Thus, HEIs can expand such untact strategy into their practices to reach their alumni and to attract new students worldwide.

\subsection{Limitation and future directions}

Like most studies, this research suffers from certain limitations. Although we collected data from both national and private HEIs in Taiwan to improve the compatibility and inclusivity of this study, our results were limited in generalization to other countries. Future studies can further prove the generalization by conducting the research in different countries and cultures. Moreover, this research only incorporated WOM/advocacy, re-patronage intention of service usage, and capability/ degree upgrading intention as the behavioral loyalty intentions. Future studies may 
include alumni's donation intention, which is an important connection and direct monetary contribution of alumni to their alma mater (Koenig-Lewis et al. 2016; Snijders et al. 2019), as another consequent construct to capture more alumni's engagement and loyalty intention. In addition, future research should incorporate alumni's citizenship behaviors, such as giving feedback, tolerance, and helping behaviors to HEI (Yi and Gong 2013; Foroudi et al. 2019; Manzoor 2020) in order to structure a more comprehensive model to depict the relationship between alumni and their alma mater.

\section{Appendix}

See Table 5.

Table 5 The measurement of constructs

\begin{tabular}{|c|c|c|c|c|}
\hline & Loading & Alpha & $\mathrm{CR}$ & AVE \\
\hline Trust in faculty & & 0.91 & 0.94 & 0.79 \\
\hline $\begin{array}{l}\text { 1. Integrity is a word I'd use when describing the university faculty } \\
\text { members }\end{array}$ & 0.83 & & & \\
\hline $\begin{array}{l}\text { 2. I was sure that the university faculty members were always acting in } \\
\text { my best interests }\end{array}$ & 0.90 & & & \\
\hline 3. I trusted the university faculty members completely & 0.91 & & & \\
\hline 4. University faculty members always kept their promises to me & 0.91 & & & \\
\hline Institution $R Q$ & & 0.89 & 0.93 & 0.76 \\
\hline 1. This university gave me a feeling of confidence & 0.88 & & & \\
\hline 2. I have faith in this university & 0.91 & & & \\
\hline 3. I felt very attached to my faculty & 0.81 & & & \\
\hline 4. I was proud to be able to study at my university & 0.88 & & & \\
\hline WOM & & 0.81 & 0.89 & 0.73 \\
\hline 1. I'd recommend my university to someone else & 0.95 & & & \\
\hline 2. I'd say positive things about the university to other people & 0.94 & & & \\
\hline Capability/degree upgrading intention & & 0.83 & 0.92 & 0.85 \\
\hline $\begin{array}{l}\text { 1. If there are other programs offered by the same school, the chances } \\
\text { are very low that I will consider that offer }(R)\end{array}$ & 0.92 & & & \\
\hline $\begin{array}{l}\text { 2. Nothing can make me accept any programs offered by the same } \\
\text { school in future }(\mathrm{R})\end{array}$ & 0.93 & & & \\
\hline Re-patronage intention of service usage & & 0.89 & 0.95 & 0.90 \\
\hline $\begin{array}{l}\text { 1. If I was faced with the same choice again, I'd still choose the same } \\
\text { university }\end{array}$ & 0.95 & & & \\
\hline 2. I'd consider the university my first choice for education & 0.95 & & & \\
\hline Participation (Member) & & 0.90 & 0.94 & 0.84 \\
\hline $\begin{array}{l}\text { 1. I'd become a member of any alumni organizations at my old univer- } \\
\text { sity }\end{array}$ & 0.89 & & & \\
\hline 2. I'd participate in the alumni activities arranged by my old school & 0.93 & & & \\
\hline 3. I'd participate in the alumni activities arranged by my old department & 0.92 & & & \\
\hline Cognitive commitment & & 0.89 & 0.93 & 0.76 \\
\hline
\end{tabular}


1. Because it was too costly to switch to another university, I kept my 0.80 enrollment in my university

2. Because no other good universities were available, I remained a student of my university

3. I remained a student of my university because it was difficult to transfer to another university

4. I remained a student of my university because it would take much time and energy to switch to another university

Goal Commitment (single item)

1 . When I set targets for myself, I always reach them

School prestige

1. People in my community think highly of my old school

2. My old school is considered one of the best in the community

3. My old school does not have a good reputation in my community ( $R$ )

4. It is considered prestigious in the community to be an alumnus of my old school

\section{Alternative attractiveness}

1. A new university would provide a full range of services

2. I would feel more satisfied with the services of a new university than 0.90 I was with this university

Service quality is a formative construct

\section{References}

Ajzen I, Driver BL (1992) Application of the theory of planned behavior in leisure choice. J Leisure Res 24:207-224. https://doi.org/10.1080/00222216.1992.11969889

Alves H, Raposo M (2010) The influence of university image on student behavior. Int J Educ Manage 24(1):73-85. https://doi.org/10.1108/09513541011013060

Anderson JC, Gerbing DW (1988) Structure equation modeling in practice: a review and recommended two-step approach. Psychol Bull 103(3):411-423. https://doi.org/10.1037/0033-2909.103.3.411

Ashforth BE, Mael FA (1996) Organizational identity and strategy as a context for the individual. Adv Strateg Manage 13:19-64

Baker AR (2019) Implications of financial concerns for college goal commitment among undergraduate students in the United States. Soc Psychol Educ 22:63-89

Bandura A (1991) Social-cognitive theory of self-regulation. Org Behav Hum Perform 50:248-287

Bendapudi N, Leone RP (2003) Psychological implications of customer participation in coproduction. J Mark 67(1):14-28. https://doi.org/10.1509/jmkg.67.1.14.18592

Berry LL (1995) Relationship marketing of services-growing interest, emerging perspectives. J Acad Mark Sci 23(4):236-245. https://doi.org/10.1177/009207039502300402

Bhattacherjee A, Limayem M, Cheung CMK (2012) User switching of information technology: a theoretical synthesis and empirical test. Inform Manage 49(7-8):327-333. https://doi.org/10.1016/j.im. 2012.06.002

Brown RM, Mazzarol T (2009) The importance of institutional image to student satisfaction and loyalty within higher education. High Educ 58:81-95. https://doi.org/10.1007/s10734-008-9183-8

Brown TJ, Dacin PA, Pratt MG, Whetten DA (2006) Identity, intended image, construed image, and reputation: an interdisciplinary framework and suggested terminology. J Acad Mark Sci 34(2):99-106. https://doi.org/10.1177/0092070305284969 
Campbell RM, Aiken D, Kent A (2004) Beyond BIRGing and CORFing: continuing the exploration of fan behavior. Sport Mark Q 13:151-157

Chang HH, Jeng DJF, Hamid MRA (2013) Conceptualising consumers' word-of-mouth behavior intention: evidence from a university education services in Malaysia. Serv Bus 7:17-35. https://doi.org/ 10.1007/s11628-012-0142-1

Chen PT, Hu HH (2010) The effect of relational benefits on perceived value in relation to customer loyalty: an empirical study in the Australian coffee outlets industry. Int J Hosp Manage 29(3):405412. https://doi.org/10.1016/j.ijhm.2009.09.006

Cialdini RB, Borden RJ, Thorne A, Walker MR, Freeman S, Sloan LR (1976) Basking in reflected glory: three football field studies. J Pers Soc Psychol 34:366-375. https://doi.org/10.1037/0022-3514. 34.3.366

Collier JE, Bienstock CC (2006) Measuring service quality in e-retailing. J Serv Res 8(3):260-275

Cronin JJ, Taylor SA (1992) Measuring service quality: a reexamination and extension. J Mark 56(3):5568. https://doi.org/10.2307/1252296

Crosby LA, Evans KR, Cowles D (1990) Relationship quality in services selling: an interpersonal influence perspective. J Mark 54(3):68-81

Diamantopoulos A, Riefler P, Roth KP (2008) Advancing formative measurement models. J Bus Res 61(12):1203-1218. https://doi.org/10.1016/j.jbusres.2008.01.009

Dick AS, Basu K (1994) Customer loyalty: toward an integrated conceptual framework. J Acad Mark Sci 22:99-113. https://doi.org/10.1177/0092070394222001

Dwyer FR, Schurr PH, Oh S (1987) Developing buyer-seller relationships. J Mark 51(2):11-27

Fares D, Achour M, Kachkar O (2013) The impact of service quality, student satisfaction, and university reputation on student loyalty: a case study of international students in IIUM Malaysia. Inform Manag Bus Rev 5(12):584-590

Fornell C, Larcker D (1981) Evaluating structural equation models with unobservable variables and measurement error. J Mark Res 18(1):39-50

Fornell C, Johnson MD, Anderson EW, Cha J, Bryant BE (1996) The American customer satisfaction index: nature, purpose, and findings. J Mark 60(4):7-18

Foroudi P, Yu Q, Gupta S, Foroudi MM (2019) Enhancing university brand image and reputation through customer value co-creation behaviour. Technol Forecast Soc Chang 138:218-227

Forsyth PB, Adams CM, Hoy WK (2011) Collective trust: why schools can't improve without it. Teachers College Press, New York

Funk DC, Haugtvedt CP, Howard DR (2000) Contemporary attitude theory in sport: theoretical considerations and implications. Sport Manage Rev 3:124-144

Gallo ML (2013) Higher education over a lifespan: a gown to grave assessment of a lifelong relationship between universities and their graduates. Stud High Educ 38(8):1150-1161. https://doi.org/10. 1080/03075079.2013.833029

Geyskens I, Steenkamp JEBM, Scheer LK, Kumar N (1996) The effects of trust and interdependence on relationship commitment: a trans-Atlantic study. Int J Res Mark 13(4):303-317

Ghazali E, Nguyen B, Mutum DS, Mohd-Any AA (2016) Constructing online switching barriers: examining the effects of switching costs and alternative attractiveness on e-store loyalty in online pureplay retailers. Electron Mark 26(2):157-171

Gustafsson A, Johnson MD, Roos I (2005) The effects of customer satisfaction, relationship commitment dimensions, and triggers on customer retention. J Mark 69(4):210-218

Hair JF, Sarstedt M, Ringle CM, Gudergan SP (2017) Advanced issues in partial least squares structural equation modeling. Sage Publications, California

Hambleton RK (1993) Translating achievement tests for use in cross-national studies. Eur J Psychol Assess 9(1):57-68

Hashim S, Mohd Yasin N, Ya'kob SA, (2020) What constitutes student-university brand relationship? Malaysian students' perspective. J Mark High Educ 30(2):180-202

Helgesen $\varnothing$, Nesset E (2007) What accounts for students' loyalty? Some field study evidence. Int J Educ Manage 21(2):126-143

Hennig-Thurau T, Langer MF, Hansen U (2001) Modeling and managing student loyalty: an approach based on the concept of relationship quality. J Serv Res 3(4):331-344

Hollenbeck JR, Klein HJ (1987) Goal commitment and the goal-setting process: problems, proposals for future research. J Appl Psychol 72(2):212-220. https://doi.org/10.1037/0021-9010.72.2.212

Holmes J (2009) Prestige, charitable deductions and other determinants of alumni giving: evidence from a highly selective liberal arts college. Econ Educ Rev 28:18-28 
Hsieh YC, Hiang ST (2004) A study of the impacts of service quality on relationship quality in searchexperience-credence services. Total Qual Manage Bus Excell 15(1):43-58

Hsueh CM (2019) Taiwan: higher education under pressure. Int High Educ 98:25-26

Huang JA, Lai CS, Hu JS, Weng RH (2014) The impact of market orientation on patient loyalty the mediation of relationship quality. Serv Bus 8:499-515. https://doi.org/10.1007/s11628-013-0204-z

Hult GTM, Sharma PN, Morgeson FV, Zhang Y (2019) Antecedents and consequences of customer satisfaction: DO they differ across online and offline purchases? J Retail 95(1):10-23

Jones MA, Mothersbaugh DL, Beatty SE (2000) Switching barriers and repurchase intentions in services. J Retail 76(2):259-274

Kim S, Lee JS (2013) Is satisfaction enough to ensure reciprocity with upscale restaurants? The role of gratitude relative to satisfaction. Int J Hosp Manage 33:118-128. https://doi.org/10.1016/j.ijhm. 2012.06.009

Kim R, Jeon M, Lee H, Choi J, Lee J, Kim S, Lee S, Seo Y, Kwon J (2018a) Trend Korea 2018. Miraebook Publishing Co., Seoul

Kim MK, Park MC, Park JH, Kim J, Kim E (2018b) The role of multidimensional switching barriers on the cognitive and affective satisfaction-loyalty link in mobile communication services: coupling in moderating effects. Comput Hum Behav 87:212-223

Koc E, Ulukoy M, Kilic R, Yumusak S, Bahar R (2017) The influence of customer participation on service failure perceptions. Total Qual Manage Bus Excell 28(3-4):390-404. https://doi.org/10.1080/ 14783363.2015.1090290

Koenig-Lewis N, Asaad Y, Palmer A, Petersone E (2016) The effects of passage of time on alumni recall of 'student experience.' High Educ Q 70(1):59-80

Kumar N, Hibbard JD, Stern LW (1994) The nature and consequences of marketing channel intermediary commitment. Mass, Cambridge

Kumar V, Pansari A (2016) Competitive advantage through engagement. J Mark Res 53(4):497-514

Kumar V, Rajan B, Gupta S, Pozza ID (2019) Customer engagement in service. J Acad Mark Sci 47:138160. https://doi.org/10.1007/s11747-017-0565-2

Lee SM, Lee D (2020) "Untact": a new customer service strategy in the digital age. Serv Bus 14(1):1-22. https://doi.org/10.1007/s11628-019-00408-2

Liang TP, Ho YT, Li YW, Turban E (2011) What drives social commerce: the role of social support and relationship quality. Int J Electron Commer 16(2):69-90. https://doi.org/10.2753/JEC1086-44151 60204

Locke EA, Latham GP (2002) Building a practically useful theory of goal setting and task motivation: a 35-year odyssey. Am Psychol 57(9):705-717

Manzoor SR, Ho JSY, Al Mahmud A (2020) Revisiting the 'university image model' for higher education institutions' sustainability. J Mark High Educ. https://doi.org/10.1080/08841241.2020.1781736

Marioulas J (2019) Taiwan: Universities in an aging society. Int High Educ 98:23-25

Ministry of Education (2018) Analysis report of college enrollment from 2019 to 2034. http://stats.moe. gov.tw/files/analysis/108higherstudent.pdf. Accessed April 142021

Moliner-Velázquez B, Fuentes-Blasco M, Gil-Saura I (2021) Segmenting customers according to online word-of-mouth about hotels. Serv Bus 15:103-130. https://doi.org/10.1007/s11628-020-00435-4

Moorman C, Deshpande R, Zaltman G (1993) Factors affecting trust in market research relationships. J Mark 57(1):81-101

Morgan RF, Hunt SD (1994) The commitment-trust theory of relationship marketing. J Mark 58(July):20-38

Ngobo PV (2004) Drivers of customers' cross-buying intentions. Eur J Mark 38(9/10):1129-1157. https://doi.org/10.1108/03090560410548906

Olavarría-Jaraba A, Cambra-Fierro JJ, Centeno E, Vázquez-Carrasco R (2018) Analyzing relationship quality and its contribution to consumer relationship proneness. Serv Bus 12:641-661. https://doi. org/10.1007/s11628-018-0362-0

O'Loughlin D, MacPhail A, Msetfi R (2015) The rhetoric and reality of research reputation: 'Fur coat and no knickers.' Stud High Educ 40(5):806-820

Osobajo OA, Moore D (2017) Methodological choices in relationship quality (RQ) research 1987 to 2015: a systematic literature review. J Relatsh Mark 16(1):40-81. https://doi.org/10.1080/15332 667.2016.1242395

Palmatier RW, Scheer LK, Houston MB, Evans KR, Gopalakrishna S (2007) Use of relationship marketing programs in building customer-salesperson and customer-firm relationships: differential influences on financial outcomes. Int J Res Mark 24:210-223 
Pansari A, Kumar V (2017) Customer engagement: the construct, antecedents, and consequences. J Acad Mark Sci 45:294-311. https://doi.org/10.1007/s11747-016-0485-6

Park SH, Kim YM (2000) Conceptualizing and measuring the attitudinal loyalty construct in recreational sport contexts. J Sport Manage 14:197-207

Pedro IM, Mendes JDC, Pereira LN (2020) Understanding alumni-alma mater commitment relationships upstream and downstream. J Mark High Educ. https://doi.org/10.1080/08841241.2020.1768200

Perin MG, Sampaio CH, Simões C, de Pólvora RP (2012) Modeling antecedents of student loyalty in higher education. J Mark High Educ 22(1):101-116

Roberts K, Varki S, Brodie R (2003) Measuring the quality of relationships in consumer services: an empirical study. Eur J Mark 37(1/2):169-196. https://doi.org/10.1108/03090560310454037

Rossiter J (2002) The C-OAR-SE procedure for scale development in marketing. Int J Res Mark 19:305-335

Sarstedt M, Hair JF, Nitzl C, Ringle CM, Howard MC (2020) Beyond a tandem analysis of SEM and PROCESS: use of PLS-SEM for mediation analyses! Int J Mark Res 62(3):288-299

Schlesnger W, Cervera A, Pérez-Cabañero C (2017) Sticking with your university: the importance of satisfaction, trust, image, and shared values. Stud High Educ 42(12):2178-2194. https://doi.org/10. 1080/03075079.2015.1136613

Schuetze HG, Slowey M (2002) Participation and exclusion: a comparative analysis of non-traditional students and lifelong learners in higher education. High Educ 44(3-4):309-327

Shabbir H, Palihawadana D, Thwaites D (2007) Determining the antecedents and consequences of donor-perceived relationship quality: a dimensional qualitative research approach. Psychol Mark 24(3):271-293

Sharma N, Patterson PG (2000) Switching costs, alternative attractiveness and experience as moderators of relationship commitment in professional, consumer services. Int J Serv Ind Manag 11(5):470-490

Shin MM, Noh EJ, Lee J (2018) Study abroad programs as a service convergence: an international marketing approach. Serv Bus 12:253-275. https://doi.org/10.1007/s11628-017-0345-6

Singh R, Rosengren S (2020) Why do online grocery shoppers switch? An empirical investigation of drivers of switching in online grocery. J Retail Consum Serv 53:1-17

Sirdeshmukh D, Singh J, Sabol B (2002) Consumer trust, value, and loyalty in relational exchanges. J Mark 66:15-37

Snijders I, Wijnia L, Rikers RM, Loyens SM (2019) Alumni loyalty drivers in higher education. Soc Psychol Educ 22(3):607-627

Snijders I, Wijnia L, Rikers RM, Loyens SM (2020) Building bridges in higher education: student-faculty relationship quality, student engagement, and student loyalty. Int J Educ Res 100:1-14. https://doi. org/10.1016/j.ijer.2020.101538

Sorenson S, Adkins A (2014) Why customer engagement matters so much now. http://www.gallup.com/ businessjournal/172637/why-customer-engagement-matters.aspx. Accessed April 142021

Tajfel H (1981) Human groups and social categories. Cambridge University Press, Cambridge

Thomas S (2011) What drives student loyalty in universities: an empirical model from India. Int Bus Res 4(2):183-192

Tinto V (1993) Leaving college: rethinking the causes and cures of student attrition, 2d edn. University of Chicago Press, Chicago

Trusheim D, Crouse J (1981) Effects of college prestige on mem's occupational status and income. Res High Educ 14(4):283-304

Ulaga W, Eggert A (2006) Value-based differentiation in business relationships: gaining and sustaining key supplier status. J Mark 70(1):119-136

Verhoef PC, Franses PH, Hoekstra JC (2002) The effect of relational constructs on customer referrals and number of services purchased from a multiservice provider: does age of relationship matter? J Acad Mark Sci 30(3):202-216

Verhoef PC, Reinartz WJ, Krafft M (2010) Customer engagement as a new perspective in customer management. J Serv Res 13(3):247-252

Vivek SD, Beatty SE, Morgan RM (2012) Customer engagement: exploring customer relationships beyond purchase. J Mark Theory Pract 20(2):122-146

Witze A (2020) Universities will never be the same after the coronavirus crisis. Nature 582:162-164

Wilkins S, Huisman J (2015) Factors affecting university image formation among prospective higher education students: the case of international branch campuses. Stud High Educ 40(7):1256-1272 
Wong S, Wong K (2011) Building relationship between education institutions and students: student loyalty in self-financed tertiary education. BIMA Bus Rev 22:1-31

Wu LW (2011) Satisfaction, inertia, and customer loyalty in the varying levels of the zone of tolerance and alternative attractiveness. J Serv Mark 25(5):310-322

Wu SH, Tsai CYD, Hung CC (2012) Toward team or player? How trust, vicarious achievement motive, and identification affect fan loyalty. J Sport Manage 26:177-191

Yi Y, Gong T (2008) If employees "go the extra mile", do customers reciprocate with similar behavior? Psychol Mark 25(10):961-986. https://doi.org/10.1002/mar.20248

Yi Y, Gong T (2013) Customer value co-creation behavior: scale development and validation. J Bus Res 66(9):1279-1284

Yoshida M, Gordon B, Nakazawa M, Biscaia R (2014) Conceptualization and measurement of fan engagement: empirical evidence from a professional sport context. J Sport Manage 28:399-417. https://doi.org/10.1123/jsm.2013-0199

Yuan YH, Wu CK (2008) Relationships among experiential marketing, experiential value, and customer satisfaction. J Hosp Tour Res 32(3):387-410. https://doi.org/10.1177/1096348008317392

Zimmerman BJ, Bandura A, Martinez-Pons M (1992) Self-motivation for academic attainment: the role of self-efficacy beliefs and personal goal setting. Am Educ Res J 29(3):663-676

Publisher's Note Springer Nature remains neutral with regard to jurisdictional claims in published maps and institutional affiliations. 